\title{
Estação Carandiru e o mundo construído pelas formas de nomeação
}

Maria Aparecida Silva Ribeiro ${ }^{1}$

A cidade de quem passa sem entrar é uma; é outra para quem é aprisionado e não sai mais dali; uma é a cidade à qual se chega pela primeira vez, outra é a que se abandona para nunca mais retornar; cada uma merece um nome diferente.

Ítalo Calvino

Há exatos dez anos, era desativado, na cidade de São Paulo, um complexo penitenciário que abrigava oito mil detentos: conhecida como Carandiru, a Casa de Detenção de São Paulo era assim chamada pela proximidade com a estação ferroviária de mesmo nome. Sua extinção se deveu, em última análise, ao incidente, transmitido em tempo real por emissoras de televisão, definido como o "massacre de Carandiru", no qual uma rebelião de presos levou à invasão da força policial do estado, resultando na morte de 191 detentos. Alguns meses antes, nesse mesmo ano de 2002, a tese de doutorado intitulada Por onde anda o narrador: Walter Benjamin e outros desvios de conduta, defendida no Departamento de Letras da PUC-Rio e da qual o presente artigo é extrato, dedicava um capítulo ao romance de Drauzio Varella, Estação Carandiru, que viria a ganhar, um ano depois, as telas do cinema, em produção de Hector Babenco.

$\mathrm{Na}$ ocasião, a pesquisa acadêmica acompanhava a emergência de uma série de narrativas produzidas na segunda metade dos anos noventa do século XX, da qual faziam parte, ainda, os romances Cidade de Deus, de Paulo Lins, Pavilhão Nove, de Hosmany Ramos, e Capão Pecado, de Ferréz, dentre outros. A temática explorada nessas obras sinalizava o interesse pela compreensão de uma realidade urbana, contemporânea, realística por princípio e violenta segundo o senso comum, que norteava a leitura de seus relatos. Na maioria dos casos, as histórias contadas, então, no formato romanesco, anteriormente, haviam circulado apenas enquanto fato jornalístico. Seus autores, estreantes na literatura em sua quase totalidade, lidavam com tais objetos de leitura - as experiências por eles vivenciadas - com a intimidade de quem, efetivamente, esteve no cenário em que os fatos relatados ocorreram. Pareciam ter sobrevivido ao inferno do qual

\footnotetext{
${ }^{1}$ Doutora em letras e professora adjunta do Departamento de Letras Vernáculas da Universidade Federal de Sergipe (UFS) e do Programa de Pós-Graduação em Letras da UFS, Aracaju, SE, Brasil. E-mail: masribeiro97@gmail.com
} 
davam, mais que notícias, uma interpretação, pela prática do narrar.

Este artigo quer, assim, distanciado em mais de uma década dos acontecimentos que alavancaram a escrita de Varella (e cujo registro literário foi analisado por pesquisa acadêmica interessada nos processos narrativos envolvidos), propor uma leitura do romance a partir das escolhas praticadas em seus processos de nomeação, os quais subsidiam a narração, segundo a formulação benjaminiana. E perscrutar os modos como o espaço, quase um personagem da história contada, é configurado pelo discurso nomeador, em sua escassez e excessos.

\section{O Nome, o Ser e a Ideia}

Referências conceituais propostas pela escrita de Benjamin - tanto as que aparecem explicitadas, como no caso de suas teses, quanto as depreendidas na leitura de sua prosa filosófica - ensejam a busca por afinidades entre aspectos da narrativa tradicional, objeto de sua argumentação (e de cujo processo de extinção ele tratara, no início do século XX) e narrativas datadas do final desse mesmo século, na literatura brasileira. A noção de nome e os processos envolvidos na nomeação dos sujeitos na prática narrativa são vias possíveis para esse encontro, caso específico da coleção de escritos que ora submetemos a tal cotejo.

Benjamin localiza a discussão sobre o nome na própria mística da origem do ser humano. Remontando à gênese bíblica, sua teoria evoca a força inauguradora da palavra adâmica. O homem, pelo dom de nomear (recebido de seu próprio Criador), inaugura sentidos para os seres que o rodeiam, tornando-se, ele próprio, senhor da natureza. Compartilha do poder da criação, quando batiza as coisas, atribuindo-lhes vida e função. Ao mesmo tempo, ele próprio também é nomeado ao nascer, o que lhe confere existência individual, bem como o conhecimento dela - o que o torna, ainda, uma espécie de "reminiscência da nomeação divina na criação: o nome próprio de um homem é a sua comunidade com o verbo criador de Deus" (Benjamin apud Muricy, 1998, p. 59).

O nome em Benjamin é, pois, uma categoria tão importante quanto ancestrais são seus domínios. Tudo o que se nomeia recebe existência junto com o nome com que é designado. E não é apenas o mundo das coisas que ganha vida ao ser nomeado: as percepções, as relações do homem com o meio também são, dessa forma, inauguradas. Como resume Muricy (1998, p. 24): só se vê bem o que se nomeia. Benjamin ilustra essa percepção da realidade atrelada à forma do nome, em uma pequena construção alegórica, publicada em Imagens do pensamento (Benjamin, 1995). Como sugere o título da obra, narra-se uma espécie de visão na qual aparecem dois bandos 
de gaivotas, bastante diferentes de todas as que se já havia observado. Por investir na construção formal das imagens extraídas da memória, como é usual em sua prosa filosófica, Benjamin transforma aquele breve e exclusivo espetáculo dos pássaros na noite em uma oportunidade única de reflexão contemplativa. Observa seu voo sequencial, ininterrupto, entrelaçado, como se, em suas asas, o destino estivesse, de algum modo, cifrado; tenta ler em seus movimentos como que sinais divinos, presságios, augúrios. E, porque via naqueles pássaros noturnos os "mensageiros indizíveis que cambiavam nos ares pretos e brancos", o nome gaivotas já não lhes cabia (Benjamin, 1995, p. 225).

Em uma espécie híbrida de crônica de viagem e relato de alucinação (ou sonho) o filósofo da linguagem ilustra de forma poética a preocupação que aparece um pouco antes, nesse mesmo volume: a de ilustrar pela palavra mais precisa experiências singulares de percepção. O balé místico daquelas aves, diante de seus olhos, o obrigava a encontrar nomes diferentes para aqueles seres, cuja função, naquele momento, também os tornava irremediavelmente diferentes das gaivotas ordinárias até ali conhecidas por esse nome. "Achar palavras para aquilo que se tem diante dos olhos - quão difícil pode ser isso! Porém, quando elas chegam, batem contra o real com pequenos martelinhos até que, como de uma chapa de cobre, dele tenham extraído a imagem" (Benjamin, 1995, p. 203).

A nomeação torna-se, assim, essencial para a conversão de formas caóticas de percepção em imagem dotada de sentidos. $\mathrm{O}$ trabalho do nomeador assemelha-se ao do escultor, já que, como este, aquele que nomeia extrai da matéria bruta - das formas indistintas de realidade - uma forma legível de acesso ao real.

Se, para Benjamin, a origem de todas as coisas e de seus sentidos está na forma de nomeação, o ser é também fruto desse processo. O teórico rompe, portanto, com uma filosofia moderna baseada na noção de um sujeito lógico, soberano na relação com os objetos que o rodeiam e lhe servem como substância de representação. A reflexão benjaminiana, antes, dilui os limites entre sujeito e objeto, buscando preferencialmente uma apresentação da realidade na forma de experimentos de linguagem.

\section{Cada uma merece um nome diferente}

Logo nas primeiras linhas, a senha: "Quando eu era pequeno assistia eletrizado àqueles filmes de cadeia em branco e preto, os prisioneiros vestiam uniformes e planejavam fugas de tirar o fôlego na cadeira do cinema" (Varella, 1999, p. 9). 
O universo obscuro e superpovoado de imagens de Estação Carandiru é, assim, construído a partir de procedimentos que em muito se afinam à dicção cinematográfica. Seu narrador não esconde a predileção por esse tipo de linguagem e o, até então, maior presídio da America Latina acaba sendo, para seu encenador, um mundo a ser configurado pela palavra e, mais especificamente, pelo nome. Os espaços, a ambiência, os personagens, as marcas de tempo, os dialetos e códigos - civil, penal, de "honra" - são elementos de um modo de enunciação que se propõe a reproduzir, imageticamente, um recorte da vida de sete mil e duzentos homens mal distribuídos por sete pavilhões.

Uma das decisões textuais relacionadas a esse empreendimento corresponde à tendência de a narrativa adotar, como seus, os processos autorreferenciais do cotidiano daquela população carcerária. As histórias, ao contrário de seus protagonistas, circulam livres, ágeis, por entre os corredores do complexo penitenciário. E esse ambiente saturado de relatos é auscultado pelo personagem narrador, o médico que põe a serviço de sua configuração de mundo cada elemento disperso, fragmentário, que vai colhendo nos dez anos de convívio e escuta atenta.

Mesmo os cacos de história que já se encontram incorporados à rotina desse mundo acabam ganhando importância na compreensão da realidade. As alcunhas dos detentos, por exemplo, tanto as adquiridas fora do presídio quanto as que decorrem de algum episódio ocorrido dentro de seus muros, fazem parte desse conjunto de peças significativas em si mesmas e no rearranjo com as demais. Seus sentidos, explicitados ou não, sempre vão dizer de seus portadores um pouco da história que carregam. $\mathrm{O}$ farto uso de epítetos, codinomes, apelidos, no modo de nomeação dos detentos merece leitura ressignificante. Cabe aqui, no entanto, aprofundar um caso em especial: o do personagem Sem Chance. Principalmente, porque o uso do apelido do personagem, oriundo do bordão por ele criado, ilustra com precisão a importância que o processo narrativo atribui à forma preliminar e sucinta de se enunciarem conceitos, os mesmos com os quais o narrador irá trabalhar durante toda a edificação do mundo da história.

Sem Chance é apresentado ao leitor, logo no quinto capítulo, como "um mulato franzino que ganhou o apelido de tanto repetir essas palavras no final da frase". E acaba ganhando, por suas inserções na narrativa, um peso cada vez maior. Presença recorrente em muitos dos capítulos e funcionando, por vezes, como uma espécie de informante preferencial, o personagem vai pontuando, com esse bordão, os relatos das ações de certos personagens. Ora no papel de juiz, ora como advogado de defesa, promotor ou simples porta-voz do senso comum, Sem Chance vai 
emitindo juízos de valor, proferindo sentenças, condenações, atribuindo culpas e selando destinos, num tom quase sempre proverbial que remete ao caráter determinista das situações comentadas. Isso permite afirmar que Sem Chance traz aos relatos certa dose de fatalidade, sinalizando a dimensão trágica das histórias de vida que circulam por aqueles espaços. Sem Chance são (ou estão), na verdade, todos os personagens de que trata o texto: sem chance, sem cura, sem salvação. Antes de ganhar um capítulo especial dando conta de sua, igualmente trágica, existência, Sem Chance, o "mulato franzinho, riso aberto, o caçula da casa" que dizia "que não era ladrão nem nada" vai construindo por suas pontuações bem-humoradas, mas também sagazes, irônicas, um mundo de escassas opções, um mundo sem acordos nem negociação, ou, pelo menos, sem muita autonomia para empreender tais relações. O rapaz que, aos dezenove anos, se envolveu com a criminalidade, segundo ele, "não por convicção, mas por não ter para onde ir. Só para não ficar sozinho" é o mesmo que, depois de dezesseis anos na Casa de Detenção, construiu sua existência dentro dos muros daquele presídio. Sua consciência aguda de que, fora dali, não há vida possível para ele é o que faz com que uma de suas últimas falas atinja o mais alto grau de dramaticidade e determinismo trágico: "Para a sociedade, eu não passo de um reles, rejeitado que nem cachorro sarnento. Se aqui na cadeia os manos não tratar eu como considerado, não vou ser nada para ninguém, sou um zero no mundo. Vou perder a identidade própria do ser humano. É sem chance" (Varella, 1999, p. 267).

Sua vida pregressa - tão franzina quanto seu corpo dilacerado pela tuberculose e pelo crack - é por ele resumida e sentenciada no momento de sua morte. E é a palavra falada, contada, que o resgata da condição de "zero no mundo". As pequenas doses de oralidade, que experimenta aos sorvos, como num vício, em todas as interferências que o texto lhe atribui, lhe devolve "a identidade própria do ser humano". É, contudo, a partir desses exercícios que não apenas o personagem em questão, mas toda a massa de seres que vão ganhando singularidade no decorrer do texto volta a ter chance. É a oportunidade que lhes dá a história contada - ainda que tal disposição - a de lhes dar a segunda (ou talvez única) chance - esteja embutida por detrás da decisão aparentemente banal de incorporar a alcunha ao texto. Por menos explícitos que os sentidos possam parecer, a escolha dessa forma de nomeação valoriza o conteúdo significativo que cada expressão abriga. Integrantes das decisões formais da narrativa, percebem-se os apelidos primeiro pelos efeitos de humor que provocam. Como marcas das relações entre os detentos - gozação, ironia, sarcasmo, diferentes graus de perversidade, conhecimento do passado, destaque 
de características físicas, de personalidade ou de atitudes -, os apelidos ultrapassam os exercícios conotativos de estilo. Acabam abrindo janelas no texto para que os sujeitos, por eles nomeados, emerjam da massa de encarcerados, ganhem distinção na narrativa, insurgindo-se como portadores de uma história individual. Cada uma dessas histórias, agregada à coletiva, isto é, a do próprio mundo que partilham, os transforma em cidadãos nessa comunidade de estranhos. E a narrativa, efetivamente, tira partido da densidade de representação contida nesse modo de nomear os elementos da história contada.

\section{Uma cidade espelho}

Não são apenas os personagens que recebem, junto com seus nomes, uma carga de significação. Os espaços também estão, de certo modo, sujeitos às formas de nomeação. Radial é, por exemplo, o nome da "movimentada avenida da zona leste da cidade". Já na Casa de Detenção, refere-se ao "caminho asfaltado que faz a ligação entre os pavilhões" (Varella, 1999, p. 18). A nomeação vai, assim, seguindo o caminho das analogias - não necessariamente reveladas -, transformando a leitura num exercício constante de levantamento de pistas.

Longe de aproximar o espaço circunscrito da Casa de Detenção do mundo exterior às muralhas, essas referências nominativas acabam transformando esse outro mundo, dentro do qual estão condenados a circular, numa réplica cada vez mais distante da cidade sobre a qual está plantado. Lembram aos habitantes dessa outra cidade que há (ou houve) uma Radial por onde transitam(vam) outras pessoas, em deslocamentos muito diversos daqueles que experimentam em seu cotidiano.

A projeção analógica entre os mundos interior e exterior às grades do Carandiru prossegue, erigindo pouco a pouco uma estrutura de cidade bastante definida e alicerçada sobre valores e códigos também precisos. A cidade cravada entre as avenidas Ataliba Leonel e Cruzeiro do Sul padece dos mesmos males e contradições, mais extremados talvez, da cidade que a circunda.

O problema do partilhamento dos espaços, por exemplo, é agudo e, para muitos dos detentos, questão de vida ou morte. No capítulo "O barraco", a questão da moradia é analisada sob vários aspectos. A "direção da Casa" justifica a falta de recursos para a manutenção das celas e entrega do "direito de posse" ao detento. Os moradores usam uma lógica bastante razoável para explicar a situação: "O companheiro gasta o dele no melhoramento do barraco. Depois, a polícia vai querer colocar outro lá para morar de graça. Cadê a justiça?" (Varella, 1999, p. 36). Os menos afortunados, "os que chegam na cadeia sem amigos nem dinheiro", acabam 
"constatando com amargura": "Ó a situação do país, doutor, tem que pagar para morar na cadeia" (Varella, 1999, p. 37).

Como em uma cidade (< constituinte de um estado < divisão política de um país), a situação econômica e, por extensão, a saúde, a segurança, os estados de espírito do Carandiru refletem as crises vivenciadas pela sociedade que o comporta. A moeda oficial desse mundo paralelo, os "maços de cigarro", sofre alteração em seus valores de compra e de venda de acordo com as manobras econômicas realizadas em um centro de poder localizado bem longe daqueles muros:

O valor do maço obedece à lei da oferta e da procura: entrou muito cigarro, o preço cai; faltou, sobe. Como a oferta flutua de acordo com a condição financeira da família que, por sua vez, reflete a situação econômica do país, nos períodos de crise nacional levam menos cigarro e o preço sobe (Varella, 1999, p. 36).

As decisões daquele centro administrativo, ainda que reverberem nas relações comerciais dessa comunidade, são analisadas segundo uma ótica bastante coerente com o tipo de vida que levam: para situações de crise, medidas extremas. Sobre o pacote econômico do Governo Collor, mais especificamente as estratégias radicais anunciadas pela então ministra da Economia Zélia Cardoso de Mello, um habitante do Carandiru assim se coloca: "Isso jamais teria se sucedido entre nós. Já imaginou, uma mocinha chegar aqui e anunciar que a grana nossa, ganhada na luta tinha congelado? Já era, doutor, não sobrava nem o pensamento na mente dela" (Varella, 1999, p. 46).

\section{O ser prisioneiro da língua}

A narrativa, por sua vez, investe (também pela apropriação dos nomes e das histórias que vêm a reboque) em um processo gradual de edificação de espaços e tempos, povoados por personagens de carne, osso, sangue e músculos movidos por paixões as mais diversas. Tal empreendimento envolve desde uma estrutura regular de construção da narrativa, decidida previamente e colocada em marcha desde o início do processo, até certas soluções textuais adotadas durante sua operacionalização. Exemplo do primeiro caso é a reprodução, a mais fiel possível, da língua falada pelos presos. Por essa prática, o autor consegue, em um primeiro momento, imprimir um tom pitoresco aos diálogos, criando efeitos de humor e apelos a uma recepção diferenciada por parte do leitor, já que este, diante de certos relatos bastante violentos e, muitas vezes, reveladores de extrema crueldade por parte dos personagens, acaba tendo sua atenção desviada para o modo como 
a história é contada. E a construção textual vai, assim, suavizando pela forma a crueza do conteúdo.

Tal procedimento - o de usar o modo de dizer dos personagens ou, segundo o próprio texto, sua "fluência da linguagem, as figuras de estilo e as gírias que mais tarde ganham as ruas", ao que se acrescentam erros de construção, certo rebuscamento vazio de expressões, adjetivação prolixa, dentre outras particularidades, sinalizado como escolha já na introdução da obra (Varella, 1999, p. 11) - apresenta outro efeito de leitura: a sensação de estar em outro território, em uma comunidade com dialeto próprio e o reconhecimento de que o mundo sobre o qual se lê é outro que não o do leitor. A cidade do Carandiru, ainda que descrita na língua (idioma) falada por seu leitor, tem suas histórias narradas em outra língua (modo de realização), de cujo domínio, no entanto, o leitor logo passa a gozar. O reconhecimento desses limites do uso da língua se dá sem muita complicação, e o resultado disso, no decorrer da leitura, é uma maior agilidade de recepção, já que, familiarizado com essa opção textual, o leitor tem diminuído o efeito de humor, pela reiterada convivência com o jargão dos personagens conarradores, e aumentada a velocidade com que se locomove pela história contada.

O impacto das soluções textuais nas relações com o leitor, bem como as mudanças de procedimentos no plano de recepção são sinalizados na própria introdução. É quando o romance apresenta o objetivo de atingir o leitor: "para que o leitor possa apreciar-lhes a fluência da linguagem" (Varella, 1999, p. 11) e criar, junto com a empatia, um caminho possível de reconhecimento, de afinidades, de sedução, já no modo como pretende configurar os personagens.

Outra regularidade no processo narrativo é a forma metafórica de que se reveste a fala dos personagens. $\mathrm{O}$ tom de seus discursos assume, muitas vezes, uma função proverbial. Os sujeitos enunciadores falam, quase sempre, de modo fabular, com "moral da história" ao final de quase toda assertiva. Sua fala, recheada de "causos", é quase sempre arrematada por expressões fixas: ditos populares, máximas oriundas do senso comum, versículos bíblicos adaptados, sabedoria popular - fragmentos do caldo cultural, próprio do acervo compartilhado de oralidade, do qual extraem seus saberes.

Típica do tratamento imagético que o modo de nomeação dá a alguns conceitos é a opção pela grafia da palavra Crime com "C" maiúsculo, tanto no registro da fala dos personagens como no da voz do narrador de terceira pessoa. À maneira simbolista, essa prática parece induzir ao entendimento do crime como uma espécie de entidade que tivesse existência à parte de seus praticantes, como se fosse uma dimensão atingida 
por alguns indivíduos e que os habilita a constituirem-se população da cidade-presídio. Seus habitantes, aliás, por manterem entre si essa origem comum, qual seja sua afiliação ao mundo do Crime, são tratados massivamente pelo texto por substantivo coletivo, tais como "a malandragem". Outros coletivos subdividem os membros da malandragem: os que acabaram de adentrar os portões da cidade, por exemplo, são os "triagens". Os "faxinas", repetidamente qualificados pelo epíteto "a espinha dorsal do presídio", se apresentam como aqueles que garantem o funcionamento das atividades vitais da Casa de Detenção - como a distribuição de quentinhas, a limpeza das áreas comuns, a relativa tranquilidade da casa pela resolução das pendências entre os presos (processos que, invariavelmente, fazem uso da força bruta para não apenas manter a máquina funcionando mas, ao mesmo tempo, conservar a si mesmos nessa posição de destaque. Estes, os faxinas, estão, portanto, no topo dessa hierarquia (Varella, 1999, p. 99), dentro da qual ainda se movem os "ratos de xadrez" - tidos como desprezíveis, por se aproveitarem de qualquer descuido dos moradores para se apropriarem de objetos pessoais, comida e qualquer outro "bem" de suas celas - e os "canelinhas", que são os presos sem direito a banho de sol diário e que, por isso, passam horas sentados em janelas gradeadas, com as pernas (ou, metonimicamente, as canelas) balançando para o lado de fora. Há ainda os considerados vilões maiores dentre essa população: a "malandragem mau-caráter, os justiceiros e estupradores" (Varella, 1999, p. 26). Para esses, apenas o "setor especial no térreo" do pavilhão Quatro, a "Masmorra", de segurança máxima - "o pior lugar da cadeia" (Varella, 1999 , p. 24) - os livra de uma pena de morte desde sempre decretada.

O coletivo presente no modo de nomeação dos personagens, além de remeter a essa origem comum, aponta ainda para a despersonalização que sofrem já na entrada na cidade: suas cabeças são raspadas, recebem a "calça jega" de uniforme, ganham alcunhas, têm seus nomes esquecidos. São, ato contínuo, transformados numa massa, ainda que heterogênea e de difícil mistura. Perdem a individualidade, a privacidade, transformando-se num ser compulsoriamente coletivo.

O cortinório é de lei, devido que senão, tem gente olhando para mim o tempo todo. Sabe lá o que é isso, doutor, entra ano e sai ano, nenhum minuto o senhor poder ficar na sua? É onde que muito companheiro de mente fraca perde as faculdades e dá cabo da própria existência (Varella, 1999, p. 39).

Por vezes, a configuração dos personagens se dá por contrastes, beirando a caricatura: "a verdadeira história" sobre o "grandão estrábico, cabelo escovinha" que é espancado até ficar cheio de escoriações por agir 
tolamente durante a distribuição das quentinhas pelos "faxinas" é relatada por "Pequeno, um rapaz franzino de língua presa, um metro e meio de altura que deu fim à vida de quatro PMs que, segundo ele, mataram seus pais". Tudo isso é descrito e concentrado em um mesmo parágrafo, arranjado de modo a realçar a estrutura de par opositivo - do tipo Davi \& Golias, o Rato \& o Leão e assim por diante (Varella, 1999, p. 46). Ainda nessa lógica de descrição por antinomias, assim como há a "vagabundagem empedernida" (uma espécie de vilões entre vilões), há também as figuras admiradas, os detentos tidos como heróis, os nigerianos presos por tráfico internacional de drogas, por exemplo, os chamados "aventureiros do tráfico", admirados e respeitados (Varella, 1999, p. 45 e 31).

A grande recorrência da estrutura narrativa, no que concerne à construção dos personagens, contudo, tem a ver com a inclusão de um aposto descritivo subsequente à identificação de cada personagem (na maioria das vezes, como já dito, nomeados por apelidos). É como se, depois de algum tempo na cadeia, ou na cidade, deixassem de ser os "triagens" e, juntamente com o novo nome, recebessem uma história. Sem Chance é ainda o melhor exemplo. "O velho Lupércio, maconheiro convicto" é outro caso importante, principalmente porque, cada vez que volta à cena, tem seu aposto acrescido de detalhes. Sua existência vai ganhando complexidade a cada aparição, à medida que tais pormenores lhe conferem status de protagonista (ou, pelo menos, de uma das inúmeras frações em que se segmenta esse protagonista coletivo). "Seu Lupércio, com mais de oitenta anos e dezenas de entradas e saídas na Casa por fumar e vender maconha" vai angariando, junto à história contada, a autoridade da velhice e

Conta que no tempo em que havia respeito, nas refeições estendia-se um cobertor Parahyba no chão do xadrez e sobre ele colocavam-se os pratos. Então, o que estava preso há mais tempo naquela cela escolhia o seu; o mais novo era o último a se servir (Varella, 1999, p. 46).

Ou que "antigamente, [...] o castigo durava noventa dias, não era essa moleza de trinta dias como agora". Aos poucos, a sabedoria acumulada nos anos vividos por Seu Lupércio vai ficando evidente pelo número de vezes que comparece à narrativa. Seus apostos tornam-se cada vez maiores e suas opiniões são, vez por outra, solicitadas. Ainda que suas afirmações sobre a "cadeia de hoje" e a de outros tempos, em certos aspectos (como no caso da incidência de estupros entre os presos) se contradigam poucas páginas depois: "antigamente era pior" (Varella, 1999, p. 50). Funcionários, policiais e outros habitantes dessa comunidade recebem, todos, esse tratamento de descrições curtas e sintéticas, localizadas nos domínios da expressão apositiva. Não se diferenciam, nesse particular, dos detentos. 
Alguns policiais guardam com estes últimos semelhanças ainda mais evidentes, como é o caso do policial transferido para a função de guardião da muralha, como uma espécie de rebaixamento "após a morte de um colega, seguida do fuzilamento de quatro membros da quadrilha que o matara" (Varella, 1999, p. 46), do qual o policial em questão parece ter participado, segundo sugere o texto.

Pela construção do texto, o personagem, antes massa desfigurada, padecendo da maldição do coletivo, volta personalizado. Nomeado, carrega uma história, um relato curto situado como aposto; só uma referência, a princípio, mas suficiente para que o ser volte à condição de sujeito, para que, ganhando singularidade, "deixe de ser zero no mundo". Alguns desses apostos guardam em suas histórias condensadas muitos dos elementos da tragédia: paixão, ciúme, violência, contados de modo sintético, quase alegórico. Uma vez nomeados por substantivos próprios e simples, individualizados por apostos, transformam-se em pessoa-personagem. Às vezes, retornam ao discurso narrativo, enriquecidos em sua descrição e, nessa volta, aparecem como velhos conhecidos da história ("seu Jeremias, aquele senhor pai de dezoito filhos com a mesma mulher" (Varella, 1999, p. 43, grifo nosso). Ou, ainda, reaparecem constituindo tema para capítulos inteiros, como no caso de Sem Chance, de Deusdete e Mané, de Edelso, de Lula, de Margô Suely, dentre outros tantos.

A narrativa, portanto, submete-se a esse modo de configuração dos personagens. Cada um dos seres carrega, atrelado ao nome, uma possibilidade de desdobramento da história, para dentro e para fora dos muros do Carandiru. Dito em outros termos: o que se apresenta como aposto é, na verdade, uma tendência a escavar ao máximo a forma descritiva, em direção a outra instância narrativa. É como se, em um primeiro momento do processo de construção textual, a ação se alojasse dentro dos parênteses da descrição do personagem, ainda que apenas potencialmente. É ainda como se o narrador testasse as possibilidades de cada personagem por meio dessas pequenas doses de história contada, para depois trazê-lo de volta, ou não, em capítulos inteiros. Outros textos poderiam ser escritos, outras cidades seriam, pela narrativa, erigidas, caso outros personagens, que não esses de que trata o discurso, fossem selecionadas para, de mero aposto, tornarem-se capítulo inteiro no curso da escrita. É assim, também, no caso da escolha dos temas e situações relatadas, de que dá conta o próximo tópico.

\section{Dos códigos e modelos}

A lógica das relações configuradas pelo texto, que faz com que a população carcerária se mova de uma maneira ou de outra dentro daquele sistema, 
obedece a um código muito estrito de valores e procedimentos. É sobre essa base referencial codificada que a narrativa vai erigindo uma cidade correspondente, em muitos aspectos, ao mundo de fora de seus muros. Evidência disso é a rigidez de sua divisão geográfica, econômica, social:

O Cinco é o pavilhão dos sem-família, dos sem texto e dos humildes. É o pavilhão da ralé (Varella, 1999, p. 29).

O Quatro contém menos de quatrocentos presos, alojados em celas individuais, caso único na Detenção, [...] no Quatro, meu filho, até eu gostaria de morar (Varella, 1999, p. 23).

A cidade, como qualquer grupamento humano abriga desigualdades, contrastes, marcas do cotidiano em seus espaços, rotinas específicas e peculiaridades funcionais: "Nesse andar, [...] o que chama a atenção do visitante é a presença de travestis, com as maçãs do rosto infladas de silicone, calças agarradas e andar rebolado. Durante o dia, alguns fazem ponto perto das celas" (Varella, 1999, p. 28).

Os espaços são marcados segundo os mais variados condicionamentos, desde pressões explícitas a acordos tácitos, passando por combinações de diversosníveis. Grande partedessas convenções obedeceàlógica proveniente das relações de poder, as quais são estabelecidas no contato e, mais precisamente, nos pontos de atrito entre sujeitos tão diversos. A origem de tais acordos, quase sempre, remonta a um tempo que antecede a ocupação do espaço por grande parte da população contemporânea ao tempo da narração. Aos que chegam - em grande número e diariamente - ao presídio e se deparam com a rigidez desses limites, só resta conformar-se ao (com o) modelo de ocupação já estabelecido, bem como aos usos e práticas locais. Não são bem-vindas, sequer toleradas, inovações nesse modelo, os mapas de uso são inalteráveis, até onde a narração informa. Tampouco se observa qualquer deslocamento dos sujeitos, não previsto pela lógica das relações fixas de poder e ocupação.

A manutenção dos valores da espacialidade que depende de (e obriga à) conformação a seus modelos de uso envolve reproduzir conceitos verbalizados e reiteradamente enunciados, ainda que seus enunciadores demonstrem pouco ou nenhum conhecimento de seus fundamentos. Assim como na construção das tradições sociais, os membros de uma coletividade garantem, pela palavra contada, um status de permanência e validade às antigas lendas; é também pela oralidade que os habitantes dessa cidade-presídio preservam e robustecem elementos de um acervo essencialmente folclórico. Geração após geração, os detentos repetem, sem mesmo refletir sobre o conteúdo de suas palavras, que: 

O Nove é um pavilhão de encontro [...]
O Oito é o problemático "fundão" [...]
O Sete é a fábrica de túnel da cadeia [...]
O Cinco é a fábrica de faca da cadeia [...]
O Dois é a entrada da cadeia (Varella, 1999, p. 21-35).

Ainda que a grande maioria jamais tenha encontrado alguém no Nove, ou nunca tenha visto um túnel fabricado no Sete ou uma faca no Cinco. Sabem por ouvir dizer. Desde sempre, ouviram dizer, daí que só pode ser verdade. A "cidade de quem é aprisionado nela" é uma cidade feita de correspondências, ainda seguindo um padrão analógico, em que para cada demanda, surge uma alternativa de satisfação: "a tal da marialouca é a aguardente tradicional do presídio" (Varella, 1999, p. 176, grifo nosso). Assim como a arma preferencial é a faca, e a moeda, como já dito, é o maço de cigarros. Podendo, também, ser negociada a força de trabalho, como nas atividades relacionadas ao termo "barraqueiro". Com essa expressão, referem-se às atividades de natureza doméstica (domus:casa:barraco>barraqueiro) empreendidas por um grupo de detentos. Tais ações envolvem a lavagem de roupas e o chamado "recorte" de alimentos. Esta atividade, peculiar à cadeia, consiste em um tratamento, digamos, culinário, dado às quentinhas vindas de fora: separação dos alimentos, que vêm misturados na embalagem térmica, em panelas; novo cozimento com temperos e corantes adicionais e/ou tempo extra dedicado a refogar, fritar, ensopar, em busca de sabores renovados para agradar o paladar de quem pode pagar por tal serviço ou é credor do barraqueiro em questão.

Outra ocupação definida como trabalho na cadeia é a de "enfermeiro", no pavilhão Quatro (espaço físico que, ao contrário do que se disse nada tem de atraente, com seus dois andares destinados a doentes graves). Há ainda as atividades de prostituição e outros serviços devidamente taxados segundo o risco que se corre ao executá-los. O comércio informal é também uma importante fonte de renda, de objetos usados. (revistas masculinas, roupas, tênis) a produtos para higiene (os trazidos pela família e negociados na cadeia), além de pastéis e sorvetes fabricados artesanalmente em algumas celas.

A estrutura analógica de cidade é confirmada por outras iniciativas, as quais refletem uma organização social que atende a determinadas necessidades. A convivência de uma variedade de templos religiosos é exemplo disso (Varella, 1999, p. 117-120). A existência da Fifa "(Federação Interna de Futebol Amador), um grupo unido de detentos experientes e respeitados, escolhidos por eleição direta entre os times de futebol de cada 
pavilhão", que coordena as partidas de futebol, é outro índice analógico (Varella, 1999, p. 46 e 47).

A descrição dos cenários, da atmosfera dos espaços, parece igualmente sugerir uma relação de correspondência com outras cidades. Em determinados momentos, o texto evoca ares de subúrbio, rotinas de fim de tarde em bairros da periferia: "A galeria está movimentada, cheia de luzes, feijão no fogo, as portas abertas, com mulheres peladas voltadas para o lado de fora, vozerio, pagode no radinho, entra-e-sai com panelas e roupas" (Varella, 1999, p. 48).

Ao lado dessa conformidade com um modelo social conhecido pelos "que passam sem entrar" naquele território, há também uma estrutura social bastante singular, enquanto realidade. E, como já dito, essa estrutura obedece a uma lógica própria, construída segundo necessidades e circunstâncias específicas. A partir dela, é que são propostos outros códigos de postura: "Entre nós um crime jamais prescreve doutor. [...] No mundo do crime, a palavra empenhada tem mais força do que um exército" (Varella, 1999, p. 10). "No Oito, cada qual carrega sua cruz, calado, o sofrimento dos anos de cadeia ensina o sentenciado a se trancar na própria solidão. É uma escola de sábios" (Varella, 1999, p. 33).

No dia a dia das celas, algumas lições - aprendidas à força da repetição e da observação das consequências de seu não acatamento - devem ser prontamente colocadas em prática: nunca acordar um preso: seu sono é sagrado; nunca entregar um parceiro (aliás, caso necessário, para angariar seu respeito, até mesmo assumir como seus os delitos por ele cometidos na cadeia); sendo o último a chegar à cela, na hora de dormir, tomar o lugar mais humilde (perto do vaso sanitário, geralmente nomeado "boi"); tomar banho, invariavelmente e sob quaisquer condições, todos os dias; não tocar (sequer chegar perto da) comida que está sendo servida, tampouco tossir ou espirrar no momento em que os "faxinas" a distribuem; pagar em dia todas as suas dívidas; não mexer em nada que não lhe pertence, sem o consentimento do dono, ainda que o julgue seu amigo; respeitar os considerados respeitáveis e desprezar os desprezíveis; não fugir a inúmeras e, por vezes incompreensíveis, regras, ainda que não as aceite ou compreenda.

Tal rosário de prescrições deriva de um código de conduta construído pela fala, mais especificamente pelos discursos produzidos no domínio da oralidade. Apreender seu conteúdo e acatar como lei cada prática implícita em suas assertivas é condição para o pertencimento a esse mundo erigido pela palavra. Conformar-se a seus modos de ocupação é prerrogativa para continuar nele (sobre)vivendo, sob pena de, além de um "zero no mundo", como todos já o são, tornar-se também um zero nessa outra coletividade. 
O narrador que emerge da escrita de Varella aparece, portanto, como um sujeito que, ao apresentar suas memórias na forma de relatos curtos e pontuais calcados na prática nomeadora, acaba por se dissolver nessa descrição de cenas e lugares. À maneira de Benjamin, na pequena coleção de aforismos, formatada em relato de memórias, intitulada Infância em Berlim, se vale de um tipo de "percepção infantil, mitológica, do mundo das coisas" (Muricy, 1998, p. 15), como denuncia já seu parágrafo de abertura. No tom sussurrante de quem se sente espectador na sala escura do cinema, povoa esse seu mundo configurado pela palavra, com personagens que também vêm a ser à medida que o relato dá conta de falas, gestos, sentimentos. Ele mesmo, o narrador de Varella, enquanto alguém que se movimenta (e se movimenta por entre) aqueles retratos, vai ganhando existência na relação de reciprocidade que se estabelece, ainda ao modo benjaminiano de se contar, enquanto descreve espaços da memória:

A tempo aprendi a me mascarar nas palavras, que, de fato, eram como nuvens. O dom de reconhecer semelhanças não é mais que um fraco resquício da velha coação de ser e se comportar semelhantemente. Exercia-se em mim por meio de palavras. Não aquelas que me faziam semelhantes a modelos de civilidade, mas sim às casas, aos móveis, às roupas (Benjamin, 1995, p. 99).

Entende-se com isso o fato de a descrição do espaço se confundir com a apresentação dos seres que por ele se movimentam. Daí, também, toda nomeação inaugurar subjetividades para personagens que deixam de ser representados por seus nomes para serem, por eles, apresentados. Daí um narrador, à maneira daquele já em vias de extinção no início do século XX, que usa histórias de vida para compor pequenas peças educativas, comprometida com certa visão saneadora de mundo, reparadora de injustiças, em outras palavras, moralmente engajada.

Em que se pese o fato de a narrativa estudada por Benjamin - tradicional, fundada na oralidade, essencialmente ética e alegórica - contrastar com os atuais relatos, autorais, algo narcísicos e afinados a uma proposta mercadológica de cultura (como o filão editorial conhecido à época como letras do cárcere, do qual Varella, do alto de seus mais de duzentos mil volumes vendidos, aparece como patrono), pode-se ainda almejar surpreender afinidades e transformá-las em problemas particulares (Benjamin, 1994, p. 220), por suas práticas discursivas e efeitos de sentido. Ao que nos deve valer ponderação de Ricoeur, criando zonas de mediação quando afirma que "talvez seja necessário, apesar de tudo, [...] acreditar que novas formas narrativas, que ainda não sabemos denominar estejam nascendo; elas atestarão que a função narrativa pode se metamorfosear, mas não morrer" (Ricoeur, 1994, p. 46). 


\section{Referências}

BENJAMIN, Walter (1994). Obras escolhidas II: Magia e técnica, arte e política. Tradução de João Paulo Rouanet. 7. ed. São Paulo: Brasiliense.

(1995). Obras escolhidas II: Rua de mão única. Tradução de R. Rodrigues Torres Filho e J. C. Martins Barbosa. 5. ed. São Paulo: Brasiliense.

CALVINO, Ítalo (1995). As cidades invisíveis. Tradução de Diogo Mainardi. São Paulo: Companhia das Letras.

MURICY, Katia (1998). Alegorias da dialética: imagem e pensamento em Walter Benjamin. Rio de Janeiro: Relume Dumará.

RICOEUR, Paul (1994). Tempo e narrativa. v. II. São Paulo: Papirus.

VARELLA, Dráuzio (1999). Estação Carandiru. São Paulo: Companhia das Letras.

Recebido em dezembro de 2012.

Aprovado em abril de 2013.

\section{resumo/abstract}

\section{Estação Carandiru e o mundo construído pelas formas de nomeação}

\section{Maria Aparecida Silva Ribeiro}

No contexto da emergência de narrativas literárias que tangenciam a crônica policial, observada no final dos anos de 1990, é publicado o romance Estação Carandiru, de Drauzio Varella. Inscrito no conjunto de textos cujos autores são estreantes em sua maioria e do qual fazem parte, ainda, as obras Cidade de Deus, de Paulo Lins, Pavilhão Nove, de Hosmany Ramos, e Capão Pecado, de Ferréz, dentre outras, o romance configura uma realidade urbana, contemporânea, realística por princípio e violenta segundo o senso comum que norteava a leitura de seus relatos. As histórias contadas, então, no formato romanesco, anteriormente, haviam circulado apenas enquanto fato jornalístico, tendo sido várias delas, posteriormente, adaptadas para o cinema. Este artigo propõe uma leitura do texto de Varella a partir das escolhas praticadas em seus processos de nomeação, os quais subsidiam a narração, consonante à configuração de narrador tradicional enunciada pelo filósofo Walter Benjamin. Quer, ainda, perscrutar os modos pelos quais o espaço, quase um personagem da história narrada, é construído pelo discurso nomeador, em sua escassez e excessos.

Palavras-chave: Drauzio Varella, espaço, nomeação, narrativa. 


\section{Estação Carandiru and the world built by the nomination forms}

Maria Aparecida Silva Ribeiro

In the context of the emergence of literary narratives about prison and violence, observed in late 1990s, Estação Carandiru, by Drauzio Varella, is published. Joined by the set of texts whose authors are mostly beginners and which comprises also Cidade de Deus by Paulo Lins, Pavilhão Nove by Hosmany Ramos and Capão Pecado by Ferréz, among others, the novel presents a urban reality, contemporary, realistic and violent according to the common sense that guided their reports. These stories, before assuming novelistic format, had circulated only as journalistic fact, several of them having been subsequently adapted for the cinema. This article proposes a reading of the text of Varella, from the choices practiced in their nomination process, which subsidize the narration, in line with traditional of the narrator setting enunciated by the philosopher Walter Benjamin. It also scrutinizes the ways in which space, almost a character in the story told, is built by nominating speech, in its excesses and shortages.

Keywords: Drauzio Varella, space, nomination, narrative. 